\title{
Biochemical Markers of Aquatic Environment Contamination - Cytochrome P450 in Fish. A Review
}

\section{Z. ŠIROKÁ, J. DRASTICHOVÁ}

Department of Toxicology, Faculty of Veterinary Hygiene and Ecology, University of Veterinary and Pharmaceutical Sciences Brno

Received June 12, 2003

Accepted November 26, 2003

\section{Abstract}

Široká Z., J. Drastichová: Biochemical Markers of Aquatic Environment Contamination Cytochrome P450 in Fish. A Review. Acta Vet. Brno 2004, 73: 123-132.

The paper reviews the most recent data on the role of cytochrome $\mathrm{P} 450$ as a biochemical marker of aquatic environment pollution. The important chemical characteristics of cytochrome P450, classification of its isoforms, its functions and involvement in the metabolism of endogenous and xenobiotic agents are described as well as methods for assessment of cytochrome P450 in biological materials. The main attention is paid to the CYP $1 \mathrm{~A}$ isoform whose detection in fish is used in toxicological monitoring of ecosystems.

Monooxygenase, EROD, pesticide, $P C B, T C D D$

The fish, as a bioindicator species, plays an increasingly important role in the monitoring of water pollution because it responds with great sensitivity to changes in the aquatic environment. The sudden death of fish indicate heavy pollution; the effects of exposure to sublethal levels of pollutants can be measured in terms of biochemical, physiological or histological responses of the fish organism (Mondon at al. 2001). Changes in age and species distribution in a stock fish population are general indicators of water pollution, but there are also responses specific to a single pollutant or a group of contaminants (Svobodová 1997). Biochemical markers are biochemical responses induced in the presence of a specific group of contaminants that have the same mechanism of toxic activity.

\section{Biochemical markers}

Entering to an organism, xenobiotics bind to specific cellular structures called receptors that are localised on the cell surface or inside the cell either in its cytoplasm or on cell organelles. The binding of a xenobiotic with its receptor may induce cellular processes that have toxic or other adverse effects on the cell. In macroorganisms, these processes subsequently affect organs, the organism itself or even the whole population involved.

Biochemical markers are measurable responses to the exposure of an organism to xenobiotics. They usually respond to the mechanism of toxic activity and not to the presence of a specific xenobiotic and, therefore, may react to a group of either similar or very heterogeneous xenobiotics. Biochemical markers detect the type of toxicity; in some of them, the magnitude of their response correlates with the level of pollution.

Biochemical markers have been used in research in toxicology, ecotoxicology and pharmacology. Most of these studies have utilised in vitro assays (White et al. 1997b; Fent et al. 1998; Rogiers and Vercruys se 1998) whereas in vivo tests have been employed in research concerned with aquatic environments (Machala 1995; White et al. 1997b; Anzenbacherová and Anzenbacher 1999; Schlenk and Di Giulio 2002). The

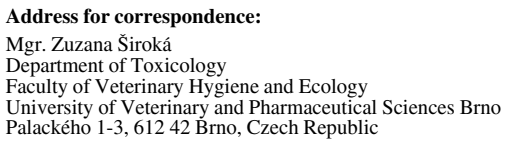


majority of reports on biochemical markers deal with pharmacological or toxicological aspects of new drugs introduced to the market.

The great advantage of biochemical markers is providing evidence of the state of pollution in a comprehensive way based on the synergistic and antagonistic effects of all contaminants involved. In fish, however, the physiological values of many parameters may vary greatly in relation to the species of fish, their age and sex as well as seasons of the year. It is, therefore, very important to seek and make use of indicators independent of such physiological fluctuation (Svobodová 1997; Schlenk and Di Giulio 2002; Jorgensen et al. 2002). One of the most intensively studied biomarkers, in both laboratory and field conditions, is cytochrome $\mathrm{P} 450$.

The determination of cytochrome P450 levels as a response of the organism to the presence of pollutants in the aquatic environment has been reported by many studies from all over the world (Payne et al. 1987; Curtis et al. 1993; Aas et al. 2001; Mondon et al. 2001; Bard et al. 2002; Jewett et al. 2002; Ruu s et al. 2002; Moore et al. 2003) including those on river pollution in the Czech Republic (Machala et al. 1997; Machala et al. 2000).

\section{Cytochrome P450}

The metabolism of xenobiotics is a two-phase process. The first phase involves reactions giving rise to more polar compounds. This may either result in reducing the effectiveness of the metabolised xenobiotic, which is described as bioelimination, or produce an active metabolite, in terms of both pharmacology and toxicology, which is regarded as bioactivation. The first-phase reactions include oxidation, reduction and hydrolysis and the greatest importance is ascribed to oxidation enzymes involved in the metabolism of the majority of xenobiotics. In second-phase reactions, the metabolites produced in the first phase or, occasionally, also the original substances, are conjugated with products of the endogenous metabolism (glucuronate, glutathione, 3'-phosphoadenosine-5'-phosphosulphate, etc.) to give rise to polar compounds subsequently eliminated from the body. Metabolites produced in the first phase are eliminated only exceptionally.

The most important oxidation enzymes of the first phase are P450 cytochromes, formerly "mixed function oxidases" (Lewis 2001). The term "cytochrome" is not very appropriate because it was initially used to designate electron-transporting proteins with a haem prosthetic group and not haem enzymes (Anzenbacherová and Anzenbacher 1999; Lewis 2001). Cytochromes are present, at high levels, in the liver, accounting for 1 to $2 \%$ mass of hepatocytes (Lester et al. 1993; Lew is 2001). However, they are also found in the intestine, kidney, lungs, brain, skin, prostate gland, placenta, etc. (Anzenbacherová and Anzenbacher 1999, 2001; Arukwe 2002; Ortiz-Delgado et al. 2002). Cytochrome P450 was described by Klingenberg in 1948 and, since then, this protein has been studied most intensively (Kvasničková 1995; Anzenbacherová and Anzenbacher 1999; Lewis 2001). As demonstrated, the enzyme is not a single entity but includes a large number of isoforms; up till now over 1000 isoenzymes have been isolated (Stoilov et al. 2001; Lewis 2001). The basic structure of each isoenzyme is a haem skeleton similar to that present in other enzymes, such as cytochrome c oxidase. Cytochrome P450 is classified as a b-type haemoprotein (haem skeleton of this type also has haemoglobin, myoglobin and certain peroxidases) associated with membranes of the endoplasmic reticulum. In eukaryotic cells, it is also bound to mitochondrial membranes and, in bacteria, it is present in the cytosol in a soluble form. Its name is derived from the fact that it was discovered as a pigment that, in a complex with CO, absorbed light at $450 \mathrm{~nm}$. The inactive form of cytochrome P450 has an absorption maximum of $420 \mathrm{~nm}$, which is similar to other haemoproteins (Kvasničková 1995; Schenkman and Jansson 1998; Anzenbacherová and 
Anzenbacher 1999). Its activity depends on the presence of NADPH-cytochrome P450 reductase and phospholipide membrane fraction. All these components constitute a monooxygenase system (Kvasničková 1995).

\section{Cytochrome P450 biochemistry}

In a simplified form, cytochrome $\mathrm{P} 450$ function is shown by the following formula:

$$
\mathrm{NADPH}+\mathrm{H}^{+}+\mathrm{RH}+\mathrm{O}_{2} \stackrel{\text { cytochrome } 450}{\longrightarrow} \mathrm{ROH}+\mathrm{H}_{2} \mathrm{O}+\mathrm{NADP}^{+}
$$

This is a monooxygenase reaction in which one molecule becomes more polar by insertion of an oxygen atom. In reality, the whole reaction is more complex because the cytochrome may utilise not only molecular oxygen but also oxygen from peroxides, and electrons may also be supplied by NADH. As mentioned above, the presence of NADPH reductase (which contains FAD and FMN prosthetic groups involved in transfer of electrons on cytochrome P450) and membrane phospholipides are also required. Cytochrome $b_{5}$ can also serve as another source of electrons (Kvasničková 1995; Anzenbacherová and Anzenbacher 1999; Lewis 2001). The reaction cycle of microsomal cytochrome P450 is presented in a scheme drawing below (Fig. 1).

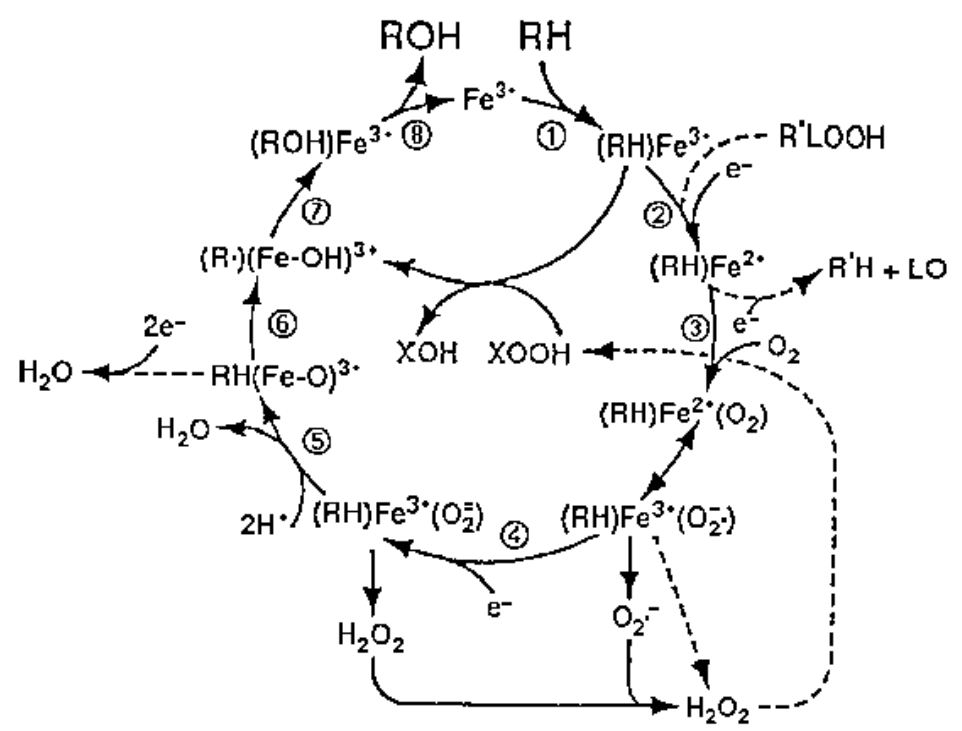

Fig. 1. Metabolic pathway of cytochrome P450 (from Anzenbacherová and Anzenbacher 1999, with permission of Bulletin CSBMB).

Mitochondria also contain monooxygenase complexes associated with cytochrome P450. These mitochondrial cytochromes are responsible for the metabolism of steroids and are also involved in the metabolism of cholesterol and the biosynthesis of steroid hormones, bile acids and vitamin D3. In these reactions, electron transfer is facilitated by ferredoxine and ferredoxine reductase (Kvasničková 1995; Anzenbacherová and Anzenbacher 1999), as shown in Fig. 2.

The cytochrome P450 group participates in a large number of different oxidation reactions, including hydroxylation, $\mathrm{H}$ - and O-dealkylation, deamination, sulphoxidation, N-oxidation, dehalogenation, etc. (Anzenbacherová and Anzenbacher 1999). 


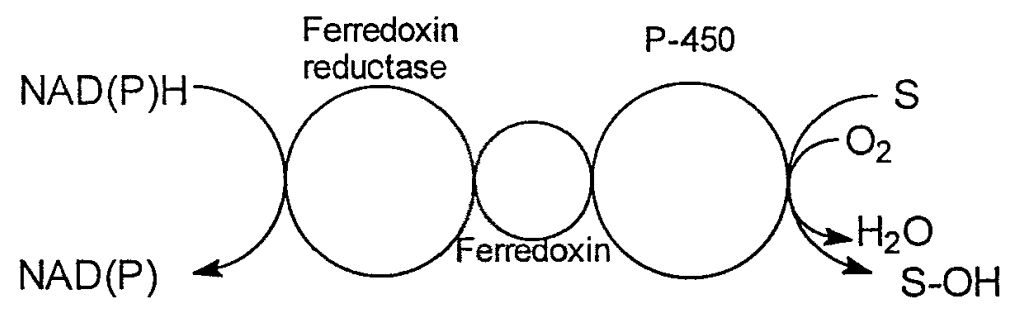

Fig. 2. Electron transfer by a mono-oxygenase complex.

\section{Nomenclature}

Cytochromes P450 (CYP) are classified into families and subfamilies on the basis of either their specific functions or presence in species. The former are designated by Arabic numerals and the latter by capital letters from A to Q (Kvasničková 1995; Anzenbacherová and Anzenbacher 1999). The most common isoforms (Lewis 2001) are listed below (Table 1).

Table 1

The present-day nomenclature of cytochromes $\mathrm{P} 450$ based on species-specificity or function

\begin{tabular}{|lll|}
\hline Family designation & \multicolumn{1}{c|}{ Characteristics } \\
\hline CYP 1 & Metabolism of foreign compounds \\
CYP & 2 & Metabolism of foreign compounds \\
CYP & 3 & Metabolism of foreign compounds \\
CYP & 4 & Metabolism of long-chain fatty acids \\
CYP & 5 & Thromboxane biosynthesis \\
CYP & 6 & Insect isoforms \\
CYP & 7 & Metabolism of steroids \\
CYP & 8 & Prostacycline biosynthesis \\
CYP & 9 & Insect isoforms \\
CYP & 10 & Mollusc isoforms \\
CYP & 11 & Biosynthesis of steroids \\
CYP & 17 & Biosynthesis of steroids \\
CYP & 19 & Biosynthesis of steroids \\
CYP & 21 & Biosynthesis of steroids \\
CYP & 24 & Metabolism of vitamin D \\
CYP & 26 & Metabolism of retinoids \\
CYP & 27 & Biosynthesis of bile acids \\
CYP & $51-70$ & Fungal isoforms \\
CYP & $71-100$ & Plant isoforms \\
CYP $101-140$ & Bacterial isoforms \\
\hline
\end{tabular}

\section{Cytochrome P450 function}

The cytochromes $\mathrm{P} 450$ are involved in a wide range of transformations of both endogenous and exogenous biological substances. Endoplasmic reticulum cytochromes are not substrate-specific. Each isoform participates in the metabolism of many different compounds. However, one substrate can also be metabolised by several different cytochrome isoforms. However, almost every isoform has its specific substrate that can be used for its identification (Kvasničková 1995; Anzenbacherová and Anzenbacher 1999, 2001; Lewis 2001). In contrast, bacterial and mitochondrial cytochrome P450 isoforms are highly substrate-specific (Lew is 2001). 
In fish, as in other animal species, there are great differences in cytochrome catalytic activity among individuals of one population as well as among populations; this is related to factors such as species, sex (e.g., estrogen suppresses the baseline but not xenobioticinduced cytochrome activity) ( Navas and Segner 2001), diet or season (Machala et al. 1997; Perkins and Schlenk 1998; Aas et al. 2001; Schlenk and Di Giulio 2002; Ruu s et al. 2002; Jorgensen et al. 2002). Inter-individual differences may be responsible for different susceptibility to a disease or disorder in members of the same species, as reported in humans (Lew is 2001). In addition, there are large inter-species differences and, in different species, the same substrate can be metabolised by different cytochrome P450 isoforms.

Although cytochromes are most frequently studied in relation to their role in the metabolism of xenobiotics, their involvement in endogenous metabolism, particularly that of steroids, is also very important ( $S$ toilov et al. 2001; Lew is 2001); in fact, this function in the organism was probably the primary one. It has been assumed that, in prehistoric organisms, cytochrome P450 was responsible for hydroxylation of organic substrates subsequently used as sources of energy. This function has been preserved up till now in some microorganisms and attempts have been made to develop microbes capable of degrading industrial contaminants of the environment that are otherwise difficult to break down (Stiborová et al. 1999). In plant organisms, production of many significant secondary metabolites, such as lignin, terpenoids, steroids, essential oils or opioid precursors (Le wis 2001), is based on cytochrome functions. The role of cytochrome P450 in endogenous metabolism is beyond the scope of this review. However, it is of a worth to mention an interesting paper by Stoilov et al. (2001) which deals with cytochrome P450 effects on endogenous metabolism and intrauterine development of the foetus.

The isoforms whose primary functions are to metabolise xenobiotics (families CYP 1, CYP 2 and CYP 3) are also known to be involved in endogenous metabolic processes in substrates such as melatonin and estradiol (CYP 1A), testosterone (CYP 3A), catecholamines (CYP 2D), progesterone (CYP 2C, CYP 3A) and arachidonic acid (CYP 2E) (Lewis et al. 2001).

In the fish, cytochrome $\mathrm{P} 450$ has primarily been studied as a biomarker indicating pollution of the aquatic environment by industrial or agricultural sewage. However, responses to xenobiotics in fish may differ from those in other species. When the results of metabolic studies of a toxin obtained in laboratory animals are to be applied to the fish, it is difficult to estimate whether cytochrome $\mathrm{P} 450$ will be induced at all or, if so, which of its isoforms will arise. For instance, cytochrome CYP 2B fails to be induced in fish (Machala 1997; Petřivalský et al. 1997; Machala et al. 1997). For detection of pollution in aquatic environments, the CYP 1 family members have been so far proved to be the most sensitive indicators (Machala et al. 1995; Machala et al. 1997; Anzenbacherová and Anzenbacher 1999; Machala et al. 2000; Schlenk and Di Giulio 2002). They respond to water contamination at levels too low to be detected by other laboratory methods or at the time when the contaminant is no longer dissolved in water but persists in the living matter, such as residues of biocidal agents. Another candidate for a biomarker is CYP $3 \mathrm{~A}$ induced in fish by some organochlorine compounds or polychlorinated biphenyls (PCBs) (Machala 1997).

In some instances, however, the presence of polycyclic aromatic hydrocarbons (PAHs) or PCBs may not induce elevated CYP 1A levels. This indicates either high concentrations of pollutants (Stegeman et al. 1997; Schlezinger and Stegeman 2001; Wirgin and Theodorakis 2002), or the presence of contaminants specifically inhibiting cytochrome P450 (e.g., Cu, Zn, Pb, Cd or Ni). Effects of stress (Jorgensen et al. 2001) or defence mechanisms allowing the fish to survive in highly polluted water should also be considered. 
It has been assumed that a suppressed expression of the Ah receptor is responsible for this resistance. This assumption, however, has not been proved (Schlenk and Di Giulio 2002). Some studies have suggested that the mechanism of this resistance may be based on post-transcription suppression of cytochrome P450 related to the dose of a xenobiotic (xenobiotics induce an increase in cytochrome mRNA but not an increase in the amount of the protein itself or its enzymatic activity). However, the mechanism of post-transcription suppression has not been fully understood. So far it has only been shown that both in vivo and in vitro administration of high PAHs doses results in destruction, by reactive oxygen radicals, of CYP 1A and ethoxyresorufin-O-deethylase (EROD), an enzyme linked with CYP 1A (White et al. 1997a; Schlezinger et al. 2000; Schlezinger and Stegeman 2001). Meyer et al (2002) found that offspring of the fish exposed to high concentrations of contaminants showed some degree of unresponsiveness to PAHs and suggested that this trait may have been incorporated in the genetic code. However, their study failed to demonstrate this quality in F2 and F3 generations, in which CYP 1A and EROD concentrations induced by PAHs were similar to the levels observed in controls. The hypothesis that the resistance to PAHs is heritable has not been confirmed by this study (Meyer et al. 2002).

Some of the xenobiotics that require cytochrome $\mathrm{P} 450$ for their metabolism are able to induce expression of this cytochrome and thus increase its amount in the organism. The most important inducers of fish CYP 1A, which is considered most relevant to pollution of the aquatic environment, include PAHs, nitrated polyaromatic hydrocarbons (NPAHs), PCBs, dioxins (TCDD) and some pesticides (Machala et al. 1995; Machala 1997; White et al. 1997b; Nilsen et al. 1998; Fent et al. 1998; Anzenbacherová and Anzenbacher 1999; Sadar and Andersson 2001; Jung et al. 2001; Schlenk and Di Giulio 2002). The members of the CYP 1A subfamily are responsible for metabolic activation of the majority of known promutagens and carcinogens that, in a long term, may be involved in cocarcinogenesis, reproductive disorders, etc. (Machala 1997; Schlenk and Di Giulio 2002).

The induction of CYP $1 \mathrm{~A}$ is mediated by the Ah receptor (AhR), a xenobiotic-binding protein present in the cytosol (Lewis 2001; S adar and Andersson 2001; Schlenk and Di Giulio 2002; Billiard et al. 2002). The receptor-contaminant complex linked to a nuclear translocator is transported to the nucleus, where its linkage to DNA results in expression of the gene coding for this cytochrome. Generally, the toxicity of a pollutant is related to the degree of its affinity to AhR. Pollutants with a high binding ability for AhR also have a high capacity to induce CYP 1A, which has adverse consequences, as described by Billiard et al. (2002).

\section{Assessment of cytochrome P450}

The degree of surface water pollution is monitored by means of indicator fish species, i.e., species most common in the region investigated. In the Labe River (Czech Republic), these are bream (Abramis brama L.), perch (Perca fluviatilis L.) and, in the Morava River (Czech Republic), this is chub (Leuciscus cephalus L.) (Svobodová 1997).

The toxicological examination includes determination of the amount of mRNA induced or measurement of the catalytic activity of the cytochrome arising in response to xenobiotic exposure. The presence of CYP 1A is associated with the activity of EROD that catalyses the production of 7-hydroxyresorufin from ethoxyresorufin. This fluorescent product can be detected by several methods, of which fluorescence spectrofluorometry is most common (Machala 1997; Nilsen et al. 1998; Chang and Waxman 1998; Machala et al. 2000; Schlenk and Di Giulio 2002). Another method evaluates the hydroxylation of benzo[a]pyrene metabolised by aryl hydrocarbon hydroxylase. However, this procedure 
requires the use of radioisotopes and is currently replaced by other methods. Cytochrome P450 can also be detected by the enzyme-linked immunosorbent assay (ELISA) because antibody against fish CYP 1A has become available (Nilsen et al. 1998; Schlenk and Di Giulio 2002).

These measurements are accurate only under specific conditions. The catalytic activity of enzymes is very sensitive to thermal denaturation (Schlenk and Di Giulio 2002) and therefore the immediate freezing of samples followed by storage at temperatures lower than $-70{ }^{\circ} \mathrm{C}$ is a prerequisite. The enzymes are also sensitive to the presence of trace metals or organic metal compounds that may destroy them or interfere with their determination (Schlenk and Di Giulio 2002).

CYP 1A determination by fluorescence spectrofluorometry

The procedure described below is based on methods reported by Nils en et al. (1998) and Chang and Waxman (1998).

Preparation of microsomes. A sample of liver tissue ( 0.5 to $2.0 \mathrm{~g}$ ) thawed on ice is placed into a homogenisation buffer ( $4 \mathrm{ml}$ per gram of tissue) and homogenised by repeating the procedure five- to seven-times. The homogenised tissue is centrifuged in Eppendorf tubes at $12000 \mathrm{~g}$ for $20 \mathrm{~min}$ at a temperature of $4{ }^{\circ} \mathrm{C}$. The supernatant (postmitochondrial supernatant, PMS) is carefully harvested, without disturbing the pellet or floating phospholipide layer, and further spun down to prepare a microsomal fraction. This centrifugation takes place in ultracentrifugation tubes at $100000 \mathrm{~g}$ for $60 \mathrm{~min}$ at $4{ }^{\circ} \mathrm{C}$. The supernatant is removed (cytosol fraction) and the microsomal pellet is resuspended in a resuspension buffer by means of a homogeniser. The fractions are maintained on ice for immediate analysis or stored at $-80{ }^{\circ} \mathrm{C}$.

Spectrophotometric analysis. The spectrophotometer monochromators are set at $535 \mathrm{~nm}$ and $585 \mathrm{~nm}$ for excitation and emission spectra, respectively. Measuring cells with controlled temperature are preferred, although reading can also be made at room temperature. Each cell is filled with $1.96 \mathrm{ml}$ EROD buffer, $10 \mu \mathrm{l}$ ethoxyresorufin solution and $20 \mu \mathrm{lmicrosomal}$ fraction. The reaction is started by adding $10 \mu \mathrm{lNADPH}$ solution. The production of resorufin is measured at 2-3 min intervals and changes in fluorescence are recorded. Subsequently, a $10 \mu \mathrm{l}$ amount of an internal resorufin standard is added and the increase in fluorescence is recorded. The protein volume in each fraction is assessed by the Lowry or Bradford methods, or with the use of a kit (bicinchonic acid kit), and the specific activity of the enzyme tested is calculated. The preparation of buffers and solutions, the formula for enzyme activity calculation and the graph for fluorescence evaluation have been described by Nilsen et al (1998).

The CYP 1A analysis can also be carried out with the use of other substrates such as 7-ethoxycoumarine (Wax man and Chang 1998; Sadar and Andersson 2001).

In addition to spectrofluorometry, cytochrome P450 can also be assessed by other methods such as high performance liquid chromatography (HPLC) (Crespi et al. 1998), ELISA, Western blotting (Nilsen et al. 1998; Tom et al. 2002) or an attachment of the reporter gene whose expression is induced in conjunction with CYP 1A (the reporter gene codes for lucipherase that is detected by bioluminescence) (Machala 1997; Williams et al. 2000). A method currently tested utilises macrophages and their oxidative function as markers for detecting exposure to PAHs (Reynaud et al. 2002).

\section{Conclusion}

In conclusion, the presence of increased CYP 1A levels is a biochemical marker that, out of a few, is accepted as an ISO standard (ISO/TC 147/SC 5 N 367 based on EROD activity 
measurement for detection of aquatic environment contamination with TCDD, PAHs and PCBs).

Changes in EROD activity, though they have a high validity, can no longer be used as the only biomarker for evaluating the degree of aquatic ecosystem pollution. Other specific indicators should also be taken into consideration as biomarkers. These are changes in activity levels of the enzymes involved in the second phase of xenobiotic metabolism, oxidation stress indicators, results of histopathological examination or indicators of contamination by xenoestrogens. The monitoring of ecosystem pollution should also involve a comparison with the results of chemical analyses of river water, riverbed sediments and indicator fish tissue.

\section{Biochemické markery kontaminace vodního prostředí - cytochrom P450 u ryb - přehled}

Cílem předložené práce je shrnout nejnovější poznatky týkající se využití cytochromu P450 jako biochemického markeru znečištění vodního prostředí. V článku jsou uvedeny nejdůležitější informace o základních chemických vlastnostech cytochromu P450, nomenklatuře jeho jednotlivých isoenzymů, jeho funkce i začlenění do metabolismu látek endogenních i xenobiotik. Rovněž jsou uvedeny metody stanovení cytochromu P450 v biologickém materiálu. Hlavní pozornost je zaměřena na isoenzym CYP $1 \mathrm{~A} 2$ cytochromu P450, jehož stanovení u ryb je využíváno v ekotoxikologickém monitoringu.

\section{Acknowledgement}

The study was supported by grant VaV 340/1/01 (The effect of chemical contamination of the environment on the quality of biological ecosystem components) from the Ministry of Environment.

\section{References}

AAS, E, BEYER, J, JONSSON, G, REICHERT, WL, ANDERSEN, OK 2001: Evidence of uptake, biotransformation and DNA binding of polyaromatic hydrocarbons in Atlantic cod and corkwing wrasse caught in the vicinity of an aluminium works. Mar Environ Res 52: 213-229

ANZENBACHEROVÁ, E, ANZENBACHER, P 1999: Cytochromy P450 a metabolismus xenobiotik. Bulletin České společnosti pro biochemii a molekulární biologii, Cytochromes P450 and xenobiotic metabolism. Bulletin of the Czech Society for Biochemistry and Molecular Biology 1: 4-33 (In Czech)

ANZENBACHEROVÁ, E, ANZENBACHER, P 2001: Review. Cytochrome P450 and metabolism of xenobiotics. Cell Mol Life Sci 58: 737-747

ARUKWE, A 2002: Complementary DNA cloning, sequence analysis and differential organ expression of naphthoflavone-inducible cytochrome P4501A in Atlantic salmon (Salmo salar). Comp Biochem Physiol C Toxicol Pharmacol 133: 613-624

BARD, SM, WOODIN, BR, STEGEMAN, JJ 2002: Expression of P-glycoprotein and cytochrome P450 1A in intertidal fish (Anoplarchus purpurescens) exposed to environmental contaminants. Aquat Toxicol 60: 17-32

BILLIARD, SM, HAHN, ME, FRANKS, DG, PETERSON, RE, BOLS, NC, HODSON, PV 2002: Binding of polycyclic aromatic hydrocarbons (PAHs) to teleost aryl hydrocarbon receptors (AHRs). Comp Biochem Physiol B Biochem Mol Biol 133: 55-68

CHANG, TKH, WAXMAN, DJ 1998: Enzymatic analysis of cDNA-expressed human CYP1A1, CYP1A2, and CYP1B1 with 7-ethoxyresorufin as a substrate. In: PHILLIPS IR and SHEPHARD EA (eds.), Methods in Molecular Biology, Vol. 107: Cytochrome P450 protocols. Humana Press Inc., Totowa, NJ, pp. 103-109

CRESPI, CL, CHANG, TKH, WAXMAN, DJ 1998: High-performance liquid chromatographic analysis of CYP2C8-catalyzed Paclitaxel $6 \alpha$-hydroxylation. In: PHILLIPS IR and SHEPHARD EA (eds.), Methods in Molecular Biology, Vol. 107: Cytochrome P450 protocols. Humana Press Inc., Totowa, NJ, pp. 123-127

CURTIS, LR, CARPENTER, HM, DONOHOE, RM, WILLIAMS, DE, HEDSTROM, OR, DEINZER, ML, BELLSTEIN, MA, FOSTER, E, GATES, R 1993: Sensitivity of cytochrome P450-1A1 in fish as a biomarker for distribution of TCDD and TCDF in the Willamette River, Oregon. Environ Sci Technol 27: 2149-2157

FENT, K, WOODIN, BR, STEGEMAN, JJ 1998: Effects of triphenyltin and other organotins on hepatic monooxygenase system in fish. Comp Biochem Physiol C Pharmacol Toxicol Endocrinol 121: 277-288

JEWETT, SC, DEAN, TA, WOODIN, BR, HOBERG, MK, STEGEMAN, JJ 2002: Exposure to hydrocarbons 10 years after the Exxon Valdez oil spill: evidence from cytochrome P4501A expression and biliary FACs in nearshore demersal fishes. Mar Environ Res 54: 21-48 
JORGENSEN, EH, CELANDER, M, GOKSOYR, A, IWATA, M 2001: The effect of stress on toxicant-dependent cytochrome P450 enzyme responses in the Arctic charr (Salvelinus alpinus). Environ Toxicol Chem 20: 25232529

JORGENSEN, EH, FOSHAUG, H, ANDERSSON, P, BURKOW, IC, JOBLING, M 2002: Polychlorinated biphenyl toxicokinetics and P4501A responses in anadromous Arctic charr during winter emaciation. Environ Toxicol Chem 21: 1745-1752

JUNG, DK, KLAUS, T, FENT K 2001: Cytochrome P450 induction by nitrated polycyclic aromatic hydrocarbons, azaarenes, and binary mixtures in fish hepatoma cell line PLHC-1. Environ Toxicol Chem 20: 149-159

KVASNIČKOVÁ, E 1995: Xenobiochemie. Carolinum, Praha, p. 49 (In Czech)

LESTER, SM, BRAUNBECK, TA, TEH, SJ, STEGEMAN, JJ, MILLER, MR, HINTON, DE 1993: Hepatic cellular distribution of cytochrome P-450 IA1 in rainbow trout (Oncorhynchus mykiss): an immunohisto- and cytochemical study. Cancer Res 53: 3700-3706

LEWIS, DFV 2001: Guide to Cytochromes P450 structure and function. Taylor \& Francis Inc., London, p. 215

MACHALA, M, PETŘIVALSKÝ, M, NEZVEDA, K, TURÁNEK, J, STUDNIČKOVÁ, Z, BIJEČKOVÁ, J, SVOBODOVÁ, Z, DRÁBEK, P 1995: Classification of pollutants based on specific modulations of components of the liver detoxifying system in rainbow trout. Aspects on Environmental Toxicology, 340-344

MACHALA, M 1997: Specifické markery mechanismů toxicity xenobiotik. Program a sborník konference ERA [Specific markers for toxicity mechanisms in xenobiotics. Abstracts of the ERA '97 Conference], pp. 211-219 (In Czech)

MACHALA, M, NEZVEDA, K, PETŘIVALSKÝ, M, JAROŠOVÁ, A, PIAČKA, V, SVOBODOVÁ, Z 1997: Monooxygenase activities in carp as biochemical markers of pollution by polycyclic and polyhalogenated aromatic hydrocarbons: choice of substrates and effects of temperature, gender and capture stress. Aquat Toxicol 37: 113-123

MACHALA, M, ULRICH, R, NEČA J, VYKUSOVÁ, B, KOLÁŘOVÁ, J, MÁCHOVÁ, J, SVOBODOVÁ, $\mathrm{Z}$ 2000: Biochemical monitoring of aquatic pollution: Indicators of dioxin-like toxicity and oxidative stress in the roach (Rutilus rutilus) and chub (Leuciscus cephalus) in the Skalice River. Vet Med-Czech 45: $55-60$

MEYER, JN, NACCI, DE, DI GIULIO, RT 2002: Cytochrome P4501A (CYP1A) in killifish (Fundulus heteroclitus): heritability of altered expression and relationship to survival in contaminated sediments. Toxicol Sci 68: 69-81

MONDON, JA, DUDA, S, NOWAK, BF 2001: Histological, growth and 7-ethoxyresorufin O-deethylase (EROD) activity responses of greenback flounder Rhombosolea tapirina to contaminated marine sediment and diet. Aquat Toxicol 54: 231-247

MOORE, MJ, MITROFANOV, IV, VALENTINI, SS, VOLKOV, VV, KURBSKYI, AV, ZHIMBEY, EN, EGLINTON, LB, STEGEMAN, JJ 2003: Cytochrome P4501A expression, chemical contaminants and histopathology in roach, goby and sturgeon and chemical contaminants in sediments from the Caspian Sea, Lake Balkhash and the Ily River Delta, Kazakhstan. Mar Poll Bull 46: 107-119

NAVAS, JM, SEGNER, H 2001: Estrogen-mediated suppression of cytochrome P4501A (CYP1A) expression in rainbow trout hepatocytes: role of estrogen receptor. Chemico-Biological Interactions 138: 285-298

NILSEN, BM, BERG, K, GOKSOYR, A 1998: Induction of cytochrome P450 1A (CYP1A) in fish. In: PHILLIPS IR and SHEPHARD EA (eds.), Methods in Molecular Biology, Vol. 107: Cytochrome P450 protocols. Humana Press Inc., Totowa, NJ, pp. 423-438

ORTIZ-DELGADO, JB, SARASQUETE, C, BEHRENS, A, GONZÁLES, DE, CANALES, MLG, SEGNER, H 2002: Expression, cellular distribution and induction of cytochrome P4501A (CYP1A) in gilthead seabream, Sparus aurata, brain. Aquat Toxicol 60: 269-283

PAYNE, JF, FANCEY, LL, RAHIMTULA, AD, PORTER, EL 1987: Review and perspective on the use of mixedfunction oxygenase enzymes in biological monitoring. Comp Biochem Physiol 86: 233-245

PERKINS, EJ, SCHLENK, D 1998: Immunochemical characterization of hepatic cytochrome P450 isoenzymes in the channel catfish: assessment of sexual, developmental and treatment-related effects. Comp Biochem Physiol C Pharmacol Toxicol Endocrinol 121: 305-310

PETRIVALSKÝ, M, MACHALA, M, NEZVEDA, K, PIAČKA, V, SVOBODOVÁ, Z, DRÁBEK, P 1997: Glutathione-dependent detoxifying enzymes in rainbow trout liver: Search for specific biochemical markers of chemical stress. Environ Toxicol Chem 16:1417-1421

REYNAUD, S, MARIONNET, D, TAYSSE, L, DUCHIRON, C, DESCHAUX, P 2002: The effects of 3methylcholanthrene on macrophage respiratory burst and biotransformation activities in the common carp (Cyprinus carpio). Fish Shellfish Immunol 12: 17-34

ROGIERS, V, VERCRUYSSE, A 1998: Hepatocyte cultures in drug metabolism and toxicological research and testing. In: PHILLIPS IR and SHEPHARD EA (eds.), Methods in Molecular Biology, Vol. 107: Cytochrome P450 protocols. Humana Press Inc., Totowa, NJ, pp. 279-294

RUUS, A, SANDVIK, M, UGLAND, KI, SKAARE, JU 2002: Factors influencing activities of biotransformation enzymes, concentrations and compositional patterns of organochlorine contaminants in members of marine food web. Aquat Toxicol 61: 73-87 
SADAR, MD, ANDERSSON, TB 2001: Regulation of cytochrome P450 in a primary culture of rainbow trout hepatocytes. In Vitro Cell Dev Biol Anim 37: 180-184

SCHENKMAN, JB, JANSSON, I 1998: Spectral analyses of cytochromes P450. In: PHILLIPS IR and SHEPHARD EA (eds.), Methods in Molecular Biology, Vol. 107: Cytochrome P450 protocols. Humana Press Inc., Totowa, NJ, pp. 25-33

SCHLENK, D, DI GIULIO, RT 2002: Biochemical responses as indicators of aquatic ecosystem health. In: ADAMS SM (ed.), Biological indicators of aquatic ecosystem stress. AFS, Bethesda, pp. 14-17

SCHLEZINGER, JJ, KELLER, J, VERBRUGGE, LA, STEGEMAN, JJ 2000: 3,3’,4,4-Tetrachlorobiphenyl oxidation in fish, bird and reptile species: relationship to cytochrome P450 1A inactivation and reactive oxygen production. Comp Biochem Physiol C Toxicol Pharmacol 125: 273-286

SCHLEZINGER, JJ, STEGEMAN, JJ 2001: Induction and supression of cytochrome P450 1A by 3,3',4,4',5pentachlorobiphenyl and its relationship to oxidative stress in the marine fish scup (Stenotomus chrysops). Aquat Toxicol 52: 101-115

STEGEMAN, JJ, WOODIN, BR, SINGH, H, OLEKSIAK, MF, CELANDER, M 1997: Cytochromes P450 (CYP) in tropical fishes: catalytic activities, expression of multiple CYP proteins and high levels of microsomal P450 in liver of fishes from Bermuda. Comp Biochem Physiol C Pharmacol Toxicol Endocrinol 116: 61-75

STIBOROVÁ, M, HUDEČEK, J, HODEK, P, FREI, E 1999: Význam cytochromů P450 pro lidské zdraví [Role of cytochrome P450 in human health]. Chem Listy 93: 229-237 (In Czech)

STOILOV, I, JANSSON, I, SARFARAZI, M, SCHENKMAN, JB 2001: Roles of cytochrom P450 in development. Drug Metab Drug Interact 18: 33-55

SVOBODOVÁ, Z 1997: Ryba - významný indikátor znečištění povrchových vod. Program a sborník konference ERA [Fish - an important indicator of surface water pollution. Abstract from the ERA Conference '97], pp. 158165 (In Czech)

TOM, M, MYERS, CR, WATERMAN, MR 2002: Evaluating molar CYP1A level in fish hepatic microsomes by competitive ELISA using recombinant membrane-free CYP1A standard protein. Aquat Toxicol 59: 101-114

WAXMAN, DJ, CHANG, TKH 1998: Use of 7-ethoxycoumarin to monitor multiple enzymes in the human CYP1, CYP2, and CYP3 families. In: PHILLIPS IR and SHEPHARD EA (eds.), Methods in Molecular Biology, Vol. 107: Cytochrome P450 protocols. Humana Press Inc., Totowa, NJ, pp. 175-179

WHITE, RD, SHEA, D, SOLOW, AR, STEGEMAN, JJ 1997a: Induction and post-transcriptional suppression of hepatic cytochrome P450 1A1 by 3,3,4,4'-tetrachlorobiphenyl. Biochem Pharmacol 53: 1029-1040

WHITE ,RD, SHEA, D, STEGEMAN, JJ 1997b: Metabolism of the aryl hydrocarbon receptor agonist 3,3,4,4'tetrachlorobiphenyl by the marine fish scup (Stenotomus chrysops) in vivo and in vitro. Drug Metab Dispos 25 : 564-572

WILLIAMS, TD, LEE, JS, SHEADER, DL, CHIPMAN, JK 2000: The cytochrome P450 1A gene (CYP1A) from European flounder (Platichthys flesus), analysis of regulatory regions and development of a dual luciferase reporter gene system. Mar Environ Res 50: 1-6

WIRGIN, II, THEODORAKIS, CV 2002: Molecular biomarkers in aquatic organisms. In: ADAMS SM (ed.): Biological indicators of aquatic ecosystem stress. AFS, Bethesda, pp. 73-82 